\title{
PENGARUH BUDAYA TERHADAP PANGAN DAN GIZI
}

\author{
Nama: Nur Faiqah Firda Muftaga
}

Nim: 70200121065

Kelas: C

\section{Pendahuluan}

Sosiologi Kesehatan adalah ilmu yang membahas tentang perilaku Kesehatan, pengaruh norma atau nilai sosial terhadap perilaku Kesehatan, serta bagaimana interaksi antar petugas Kesehatan dengan masyarakat. Sedangkan antropologi adalah sesuatu yang menekankan pada unsur-unsur budaya misalnya tabu, kepercayaan tertentu mengenai sakit penyakit.

Kebudayaan adalah tindakan serta hasil karya manusia dalam kehidupan yang berhubungan dan dimiliki oleh manusia. Budaya sangat berpengaruh pada sistem pangan, oleh karena itu objek umum masyarakat harus diketahui baik itu perilaku, kebiasaan individu atau masyarakat, dan sudut pandang. Budaya dan Kesehatan dipengaruhi oleh kebiasaan.

Gizi dan Kesehatan merupakan kebutuhan pada setiap individu dari semua kalangan baik sehat atau sakit, kaya atau miskin. semua orang butuh gizi agar status Kesehatan baik terutama bagi anak. Pengembangan kesehatan nasional berfungsi agar terwujudnya Kesehatan yang optimal walaupun penyakit tidak dapat ditolak akan tetapi dapat dihindari atau dicegah.

\section{Pola Budaya Terhadap Pangan}

Kebudayaan adalah seluruh sistem gagasan dan ras, tindakan serta karya yang dihasilkan manusia dalam kehidupan bermasyarakat yang dijadikan miliknya dengan belajar. Dengan demikian demikian maka dapat dikatakan bahwa makanan atau kebiasaan makan merupakan suatu produk budaya yang berhubungan dengan sistem tingkah laku dan tindakan yang terpola dari suatu komunitas masyarakat tertentu. Sedangkan makanan yang merupakan produk pangan sangat tergantung dari faktor pertanian di daerah tersebut dan merupakan produk dari budaya juga.

Budaya memiliki pengaruh yang besar dalam menentukan pola makan masyarakat tertentu. Masih banyak pantangan serta mitos yang masih dipercayai masyarakat mengenai pola makan. Hal ini menyebabkan rendahnya konsumsi makanan di dalam suatu masyarakat. Rendahnya konsumsi makanan juga disebabkan oleh timbulnya penyakit, terutama penyakit yang berkaitan dengan pencernaan. Produksi makanan juga dapat mempengaruhi tingkat konsumsi makanan yang rendah. Hal ini disebabkan karena masih banyaknya petani yang menggunakan teknologi tradisional.

Di Indonesia, keberagaman suku yang dimiliki menyebabkan adanya perbedaan dalam pemilihan makanan pokok. Bagi masyarakat Sunda dan Jawa, makanan pokok yang dikonsumsi adalah nasi. Sementara itu, masyarakat Madura mayoritas mengkonsumsi Jagung sebagai makanan pokoknya. Adanya perbedaan pemilihan makanan pokok ini menunjukkan 
adanya persepsi dan penilaian terhadap makanan sebagai sebuah budaya pokok di dalam suatu masyarakat. Hal ini dapat menjadi dasar mengapa bagi masyarakat Sunda, jika belum makan nasi dianggap mereka belum makan meskipun mereka telah memakan jenis makanan berat selain nasi. Dalam proses pengolahan pangan pun berbeda-beda pada setiap daerah sesuai budayanya masing-masing. Seperti di palu terdapat makanan yang dinamakan kaledo yang terbuat dari daging sedangkan di jawa makanan yang terbuat dari daging yang dinamakan rawon. Adapun di papua sagu dibuat menjadi papeda sedangkan di Sulawesi selatan tepatnya di makassar itu dibuat menjadi kapurung. Dari sini kita dapat melihat bahwa keberagaman suku dan budaya di Indonesia mempengaruhi pangan dapat dilihat dari cara mengolah makanan di setiap suku dan budaya yang berbeda-beda.

\section{Sistem Budaya Terhadap Pangan}

Berbagai sistem budaya memberikan peranan dan nilai yang berbeda-beda terhadap makanan, misalnya bahan-bahan makanan tertentu oleh suatu budaya masyarakat dapat dianggap tabu atau bersifat pantangan untuk dikonsumsi karena alasan sakral tertentu atau sistem budaya yang terkait didalamnya. Disamping itu ada jenis makanan tertentu yang di nilai dari segi ekonomi maupun sosial sangat tinggi eksistensinya tetapi karena mempunyai peranan yang penting dalam hidangan makanan pada sesuatu perayaan yang berkaitan dengan kepercayaan masyarakat tertentu maka hidangan makanan itu tidak diperbolehkan untuk dikonsumsinya bagi golongan masyarakat tersebut.

Ada juga yang beranggapan muncul dari sistem budaya seperti dalam mengkonsumsi hidangan makanan di dalam keluarga, misalnya tidak diperbolehkan memulai makan sebelum kepala keluarga atau bapak belum ada atau belum makan. biasanya sang ayah sebagai kepala keluarga akan diprioritaskan mengkonsumsi lebih banyak dan pada bagian-bagian makanan 24 yang mengandung nilai cita rasa tinggi. Sedangkan anggota keluarga lainnya seperti sang ibu dan anak-anak mengkonsumsi pada bagian-bagian hidangan makanan yang secara cita-rasa maupun fisiknya rendah. Sebagai contoh yang lain pada sistem budaya masyarakat di Timor adalah apabila dihidangkan makanan daging ayam, maka sang ayah akan mendapat bagian paha atau dada sedangkan sang ibu dan anak-anak akan mendapat bagian sayap atau lainnya.

Contoh lain yang berhubungan dengan sistem budaya ialah banyak juga terjadi pada masyarakat di perkotaan, masyarakat di perkotaan mempunyai gaya hidup atau budaya yang tingkat kesibukannya tinggi karena alasan pekerjaan. Ibu-ibu di daerah perkotaan yang kurang atau tidak menyusui bayinya dengan ASI setelah melahirkan melainkan hanya diberi susu formula bayi yang instant. Padahal ASI sangat penting untuk pertumbuhan dan perkembangan fisik bayi,

\section{Masalah Budaya Terhadap Pangan}

Memahami akan adanya budaya, kebiasaan dan sistem sosial masyarakat terhadap makanan seperti pola makan, tabu atau pantangan, gaya hidup, gengsi dalam mengkonsumsi jenis bahan makanan tertentu, ataupun prestise dari bahan makanan tersebut yang sering terjadi di kalangan masyarakat apabila keadaan tersebut berlangsung lama dan mereka juga belum 
memahami secara baik tentang pentingnya faktor gizi dalam mengkonsumsi makanan maka tidak mungkin dapat berakibat timbulnya masalah gizi atau gizi salah.

Masalah gizi rentang terkena bagi ibu hamil, menyusui, bayi dan anak-anak balita serta orang lanjut usia maka kondisi ini akan lebih rentan terhadap timbulnya masalah gizi kurang. Kekurangan atau kelebihan gizi dapat menyebabkan penyakit salah satunya yaitu stunting.

stunting adalah masalah kurang gizi kronis yang disebabkan oleh asupan gizi yang kurang dalam waktu cukup lama akibat pemberian makanan yang tidak sesuai dengan kebutuhan gizi. Stunting terjadi mulai janin masih dalam kandungan. Stunting merupakan salah satu masalah gizi yang berdampak buruk terhadap kualitas hidup anak dalam mencapai titik tumbuh kembang yang optimal sesuai potensi genetiknya. Stunting dapat menghambat proses tumbuh kembang pada balita. Menurut bentuknya gizi terbagi menjadi 4 yaitu:

- Gizi kurang

- Gizi lebih

- Kurang Gizi spesifik

- Gizi tak seimbang

\section{Solusi Budaya Terhadap Pangan}

Seperti yang kita ketahui bahwa budaya dan makanan merupakan penyebab masalah gizi yang dapat berdampak bagi Kesehatan manusia. Sehingga kita perlu memahami perilaku, kebiasaan individu ataupun masyarakat.

Adapun Langkah-langkah yang dapat kita lakukan untuk memulai perbaikan struktur sosial masyarakat tentang pandangan mereka tentang bahan makanan yang meskipun lokal akan tetapi kaya akan gizi.

- Perbaikan gizi pada keluarga

- Perbaikan budaya masyarakat dengan pengaruh utama gender terutama pada keluarga

- Pemberian makanan tambahan

- Penyuluhan gizi terpadu

- Melakukan pengkajian atau penelitian dan riset untuk melihat pengaruh budaya terhadap makanan itu sendiri 


\section{Daftar Pustaka}

https://scholar.google.com/citations?view_op=view_citation\&hl=id\&user=5xW4cx4AAAAJ \&citation_for_view=5xW4cx4AAAAJ:kNdYIx-mwKoC

Imanuddin, La Banudi. 2017. Sosiologi dan Antropologi Gizi. Kendari: Forum Ilmia Kesehatan. 